\title{
Tendências de precarização do ensino superior privado no Brasil
}

\section{Trends of precariousness in private higher education in Brazil Tendencias de precariedad en la educación superior privada en Brasil \\ CARLOS EDUARDO BIELSCHOWSKY \\ ORCID iD: http://orcid.org/0000-0001-6157-4663 \\ Universidade Federal do Rio de Janeiro}

\begin{abstract}
Resumo: O trabalho analisa, com base nos microdados do INEP, as consequências da concentração de matrículas no ensino superior em 10 grandes grupos privados, responsáveis por 48,1\% das matrículas em 2018. Mostra que tal concentração prejudica a qualidade do ensino, com 49,1\% dos alunos desses grupos em cursos cujo último conceito Enade era na faixa 1 ou 2, contra $36,9 \%$ para os alunos das outras 2.000 IES privadas e $15,8 \%$ dos alunos das IES públicas. Mostra também que leva a maior evasão: 44,0\% dos alunos daqueles grupos são desligados de seus cursos nos primeiros dois anos, comparado com $27,1 \%$ das outras IES privadas e $22,5 \%$ das públicas.
\end{abstract}

Palavras-chave: Ensino superior. Qualidade. Evasão. Oligopólio.

\begin{abstract}
The work analyzes the consequences of the concentration of enrollments in bigher education in ten large private groups, with $48.1 \%$ of enrollments in this sector in 2018 . It shows that the concentration of enrollments has a negative impact in the quality of education, with 49.1\% of students in these large groups in courses whose last Enade concept (20162018) was insufficient, in the range 1 or 2, against 36.9\% for students from all the other 2,000 private HEIs and $15.8 \%$ of students from public HEIs. It also shows that this movement leads to greater dropout, with $44.0 \%$ of students from the 10 large private groups disconnected from their courses in the first two years of the course, compared with $27.1 \%$ of other private HEIs and $22.5 \%$ of public HEIs.
\end{abstract}

Keywords: Higher education. Quality. Dropout. Oligopoly.

Resumen: El trabajo analiza las consecuencias de la concentración de las matriculas en la educación superior en diez grandes grupos privados, con el $48.1 \%$ de las matrículas en este sector en 2018. Muestra que la concentración de las matriculas perjudica la calidad de la educación, con el $49.1 \%$ de los estudiantes en estos grandes grupos en cursos cuyo último concepto Enade (2016-2018) fue insuficiente, en el rango 1 o 2, contra el 36.9\% para los estudiantes de las otras 2,000 IES privadas y el 15.8\% de los estudiantes de IES públicas. También muestra que este movimiento conduce a una mayor deserción, con el $44.0 \%$ de los estudiantes de los 10 grandes grupos privados desconectados de sus cursos en los primeros dos años del curso en comparación con el $27.1 \%$ de otras IES privadas y el $22.5 \%$ de las IES públicas.

Palabras-clave: Educación superio. Calidad. Deserción; Oligopolio. 


\section{INTRODUÇÃO}

O ensino superior no Brasil cresceu 256\% em duas décadas, passando de 2,37 milhões de matrículas em 1999 para 8,45 milhões em 2018. Entre 1999 e 2006, o subsistema privado cresceu algo mais rapidamente que o público, passando de 65\% das matrículas totais a 75\%; a partir de 2006, os dois subsistemas, o público e o privado, cresceram proporcionalmente, mantendo o sistema com um quarto público e três quartos privado.

No conjunto da Educação Superior, cresceu mais rapidamente o segmento de Educação a Distância (EaD), passando de 14,6\% das matrículas em 2010 para 23,3\% em 2018. Em particular, no setor privado, a EaD, em 2018, alcançou $29,6 \%$ do total de matrículas e 45,7\% do total de novos ingressos.

A expansão da educação superior no Brasil contém muitos méritos, mas seus problemas não são pequenos; são especialmente grandes no que se refere ao subsistema privado. O presente estudo volta-se ao comportamento desse subsistema, dá indicações de que uma forma especial de oligopólio foi implantada, pela alta concentração do "mercado" em uns poucos grupos empresariais: em 2018, dez grupos empresariais privados eram responsáveis por cerca de $50 \%$ das matrículas e captaram cerca de 60\% dos novos ingressos do setor privado. Isso parece estar lhes dando poder de imprimir um comportamento de obtenção de alta lucratividade e, de maneira geral, baixa qualidade de ensino. Se os dados sobre desempenho ainda não estão suficientemente apurados, há indícios claros de sérios problemas na oferta, o que indica baixa avaliação dos alunos no Enade, altas taxas de evasão e alta relação aluno/professor, entre outros elementos.

Este artigo está dividido em quatro partes, além da introdução. $\mathrm{Na}$ seção 2 trazemos dados sobre a evolução da educação superior, fazendo algumas comparações internacionais e analisando mudanças no perfil de oferta das Instituições de Ensinos Superior (IES) privadas nos últimos sete anos. Na seção 3 apresentamos resultados básicos no que se refere a: qualidade de ensino a partir dos resultados dos alunos no Enade, índices de evasão, custo aluno/ano e relação aluno/professor, utilizando microdados do Enade do período de 2015 a 2018 e microdados do Censo da Educação Superior entre 2010 e 2018.

Uma vez que esse movimento das IES privadas está fortemente relacionado ao crescimento da Educação a Distância, e que parte dessa oferta tem indícios de baixa qualidade (BIELSCHOWSKY, 2018), apresentamos na seção 4 um rápido histórico da regulação e supervisão da EaD no Brasil desde 2000. Na quinta seção fazemos um prognóstico da educação superior privada no país, pautado nos resultados obtidos nas seções anteriores, e apresentamos as conclusões deste trabalho. 


\section{CONTEXTUALIZAÇÃO DO ENSINO SUPERIOR}

O Gráfico 1 mostra a evolução das matrículas do setor público e privado desde 1999 (INEP, s/d).

\section{Gráfico 1 - Evolução das matrículas no ensino superior no Brasil desde 1999}

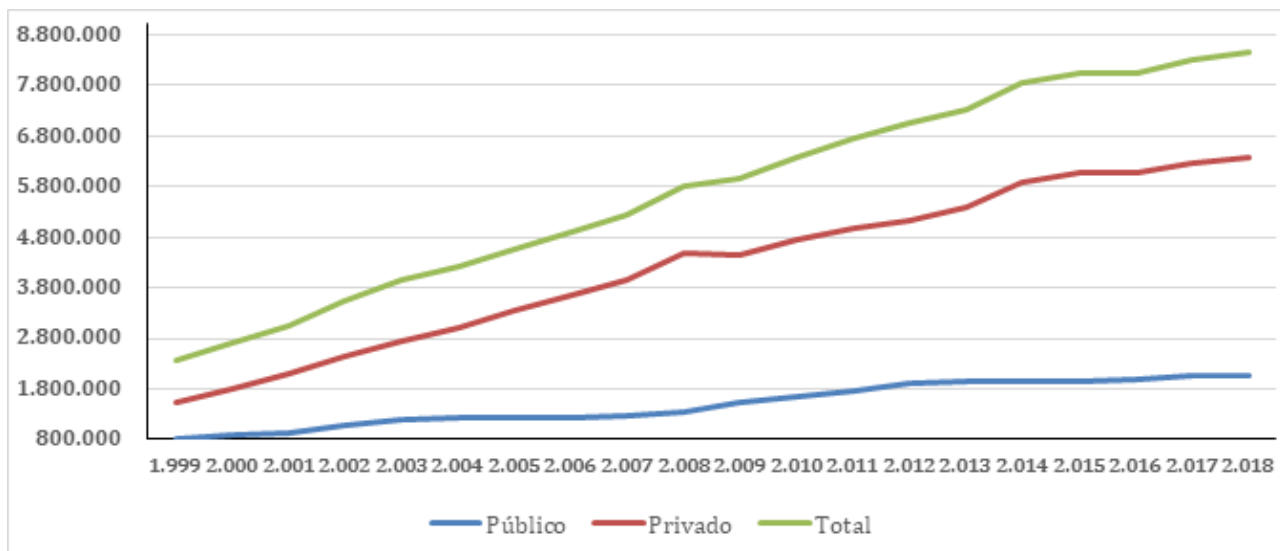

Fonte: Microdados do INEP

Esse crescimento permitiu ao país sair de entre os piores índices de inclusão da população no ensino superior do mundo, inclusive quando comparado com os demais países da América Latina, para uma posição mais adequada, ainda inferior aos países mais desenvolvidos, conforme demonstramos na Tabela 1. Essa tabela mostra a evolução da taxa bruta de matrículas no ensino superior em diferentes países entre 2000 a 2017; a taxa bruta de matrículas no ensino superior é o número de alunos matriculados no ensino superior (independentemente da idade) dividido pelo número de jovens entre 18 e 23 anos. 
Tabela 1 - Evolução da taxa bruta de matrículas no ensino superior

\begin{tabular}{|c|c|c|c|c|c|}
\hline \multirow{2}{*}{ Brasil } & $\mathbf{2 0 0 5}$ & $\mathbf{2 0 0 8}$ & $\mathbf{2 0 1 1}$ & $\mathbf{2 0 1 4}$ & $\mathbf{2 0 1 7}$ \\
\cline { 2 - 6 } & $\mathbf{2 6 , 0}$ & $\mathbf{3 5 , 6}$ & $\mathbf{4 3 , 5}$ & $\mathbf{4 9 , 9}$ & $\mathbf{5 1 , 3}$ \\
\hline América Latina e Caribe & 31,1 & 39,2 & $\mathbf{4 3 , 8}$ & $\mathbf{4 7 , 7}$ & 51,8 \\
\hline Argentina & 64,0 & 68,1 & 76,3 & 81,0 & 90,0 \\
\hline Colômbia & 30,7 & 36,1 & 43,0 & 51,4 & 56,4 \\
\hline Chile & 49,4 & 56,7 & 72,3 & 82,8 & 88,5 \\
\hline Uruguai & 45,3 & 50,9 & $\ldots$ & 60,7 & 63,1 \\
\hline México & 24,2 & 26,1 & 28,3 & 31,1 & 40,2 \\
\hline Estados Unidos & 80,6 & 85,0 & 93,9 & 88,6 & 88,2 \\
\hline Espanha & 67,2 & 69,7 & 80,0 & 85,4 & 88,9 \\
\hline França & 53,9 & 52,5 & 55,6 & 61,5 & 65,6 \\
\hline Portugal & 55,4 & 61,6 & 68,4 & 65,5 & 63,9 \\
\hline Rússia & 72,6 & 74,9 & 76,2 & 78,5 & 81,9 \\
\hline Europa & 63,0 & 66,2 & 69,0 & 69,7 & 71,6 \\
\hline China & 19,1 & 20,7 & 25,6 & 42,4 & 49,1 \\
\hline Mundo & 24,3 & 27,1 & 31,4 & 35,8 & 37,9 \\
\hline
\end{tabular}

Fonte: Unesco (2019).

Nota-se que o crescimento de matrículas a partir de 2006 se deu tanto no ensino público quanto no privado, ficando o percentual relativo de matrículas do setor público em torno de $25 \%$ ao longo dos últimos 10 anos, conforme mostra o Gráfico 2.

\section{Gráfico 2 - Percentual de matrículas nos setores público e privado desde 2007}

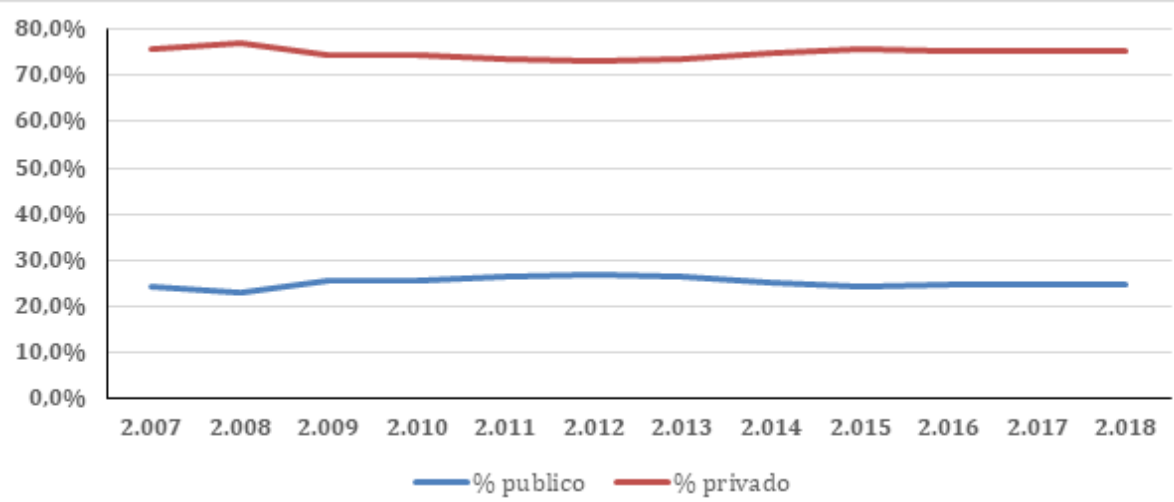

Fonte: Microdados do INEP 
O percentual de participação de alunos do ensino superior privado é majoritário no Brasil. Entretanto, isso não ocorre na maioria dos países do mundo, conforme ilustra o Gráfico 3, com os percentuais do ensino privado em países com mais de 200 mil alunos no ensino superior em 2010 (PROPHE, 2018).

Gráfico 3 - Percentual de alunos no ensino privado para os 63 países com mais de 200 mil alunos em 2010

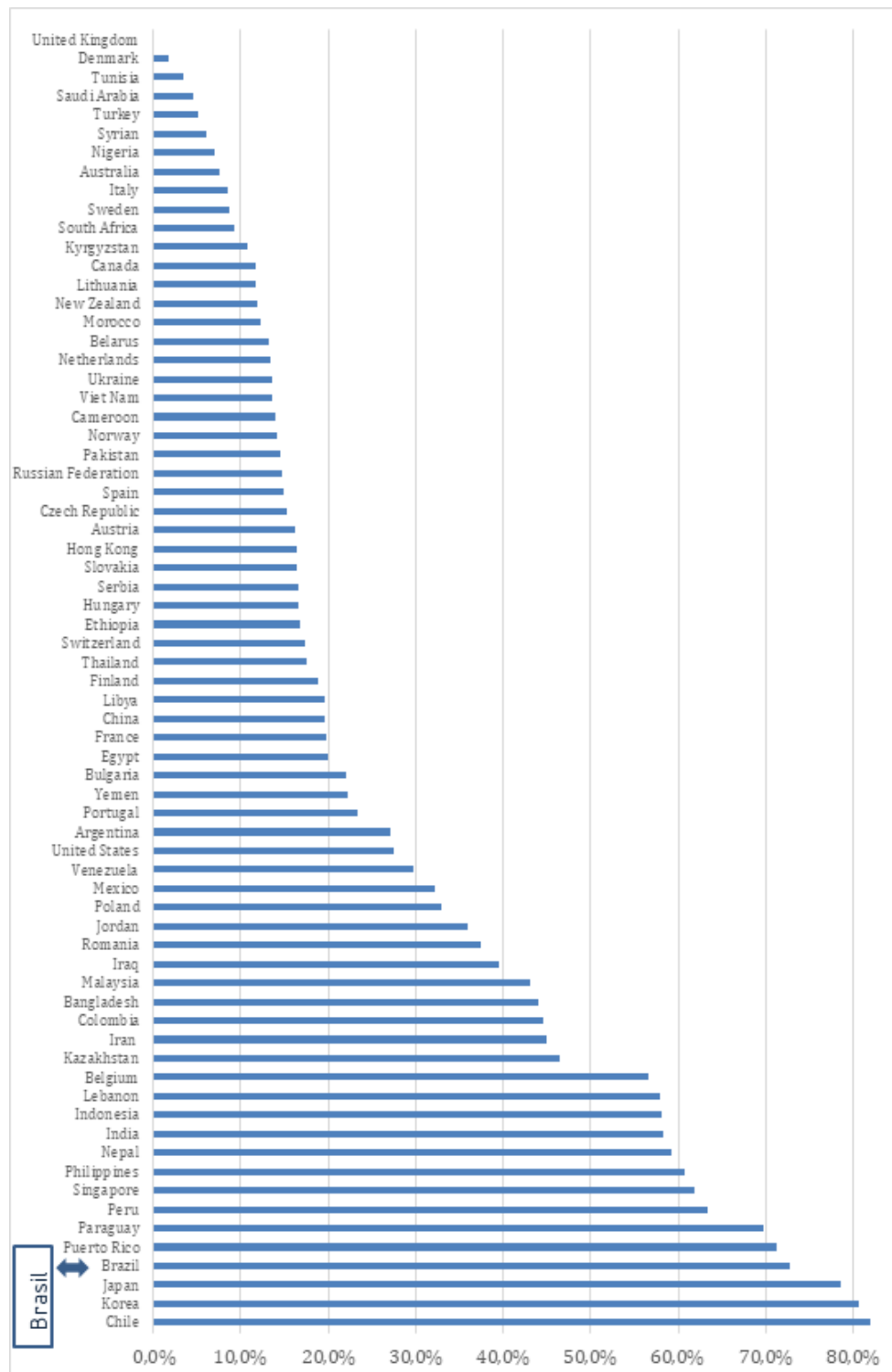

Fonte: PROPHE (2018). 
O Gráfico 3 mostra que, em países com mais de 200 mil alunos no ensino superior, apenas Chile, Japão e Coreia tinham em 2010 maior participação percentual do setor privado que o Brasil, situação bem distinta da grande maioria dos países do mundo. Nos EUA, o setor privado em 2016 foi responsável por $35 \%$ dos diplomas de bacharelado, dos quais apenas $6 \%$ em instituições privadas com fins lucrativos; $65 \%$ dos diplomas foram obtidos em IES públicas (U. S. DEPARTMENT OF EDUCATION, 2018). Na Europa, segundo Kwiek (2018), o ensino privado não tem prosperado de forma significativa: "na maioria dos sistemas europeus, prestígio e alto ranking internacional estão correlacionados com pesquisa avançada, que geralmente não está associada com o ensino privado". Em 2010 o ensino privado na Europa respondia por apenas 14,9\% das matrículas (LEVY, 2018).

Enquanto o setor público tem mantido aproximadamente o perfil de oferta nos últimos 10 anos, o setor privado tem mudado bastante, principalmente devido a três fatores: crescente concentração de matrículas em poucos grupos empresariais do ramo da educação; crescimento de matrículas em IES particulares com fins lucrativos; e maior participação percentual de alunos de EaD.

Em 2018, apenas 10 grupos empresariais, 9 dos quais com fins lucrativos, detinham $48 \%$ das matrículas das IES particulares e $60 \%$ das novas matrículas. A Tabela 2 mostra o percentual; a Tabela 3, o número de IES, matrículas e ingressantes em 2018 para os 10 maiores grupos privados, comparados com as demais IES particulares do país.

Tabela 2 - percentual de IES, matrículas e ingressos em 2018 dos 10 maiores grupos privados no conjunto das IES privadas

\begin{tabular}{|c|c|c|c|c|c|c|c|}
\hline & $\begin{array}{c}\text { Número de } \\
\text { IES }\end{array}$ & $\begin{array}{c}\text { Matrículas } \\
\text { no } \\
\text { presencial }\end{array}$ & $\begin{array}{c}\text { Matrículas } \\
\text { em EaD }\end{array}$ & $\begin{array}{c}\text { Matrículas } \\
\text { totais }\end{array}$ & $\begin{array}{c}\text { Ingressos } \\
\text { em 2018- } \\
\text { presencial }\end{array}$ & $\begin{array}{c}\text { Ingressos } \\
\text { em 2018- } \\
\text { EaD }\end{array}$ & $\begin{array}{c}\text { Ingressos } \\
\text { em 2018- } \\
\text { total }\end{array}$ \\
\hline $\begin{array}{c}\text { Participação \% } \\
\text { dos 10 maiores } \\
\text { grupos do } \\
\text { ensino superior } \\
\text { privado }\end{array}$ & $10,6 \%$ & $33,9 \%$ & $81,9 \%$ & $48,1 \%$ & $41,3 \%$ & $81,3 \%$ & $59,6 \%$ \\
\hline
\end{tabular}

Fonte: Levantamento do autor com base nos microdados do Inep. 


\section{Tabela 3 - IES, matrículas e novos ingressos dos 10 maiores grupos privados em 2018}

\begin{tabular}{|c|c|c|c|c|c|c|c|}
\hline $\begin{array}{c}\text { Grupos } \\
\text { educacionais }\end{array}$ & $\begin{array}{c}\text { Número de } \\
\text { IES }\end{array}$ & $\begin{array}{c}\text { Matrícula no } \\
\text { presencial }\end{array}$ & $\begin{array}{c}\text { Matrícula } \\
\text { em EaD }\end{array}$ & $\begin{array}{c}\text { Matrículas } \\
\text { totais }\end{array}$ & $\begin{array}{c}\text { Ingressos } \\
\text { no } \\
\text { presencial }\end{array}$ & $\begin{array}{c}\text { Ingressos } \\
\text { em EaD }\end{array}$ & $\begin{array}{c}\text { Ingressos } \\
\text { totais }\end{array}$ \\
\hline Kroton & 100 & 368.640 & 473.160 & 841.800 & 174.142 & 362.156 & 536.298 \\
\hline Unip & 33 & 254.819 & 224.032 & 478.851 & 116.050 & 145.874 & 261.924 \\
\hline Estácio & 38 & 288.024 & 163.322 & 451.346 & 103.207 & 115.127 & 218.334 \\
\hline Laureate & 11 & 225.985 & 43.483 & 269.468 & 97.870 & 32.471 & 130.341 \\
\hline Cruzeiro do Sul & 10 & 114.658 & 112.944 & 227.602 & 50.393 & 85.150 & 135.543 \\
\hline Leonardo da Vinci & 3 & 6.039 & 203.889 & 209.928 & 1.491 & 115.688 & 117.179 \\
\hline Uninter & 1 & 2.955 & 182.625 & 185.580 & 1.504 & 117.962 & 119.466 \\
\hline Uninove & 1 & 127.001 & 34.228 & 161.229 & 52.783 & 24.501 & 77.284 \\
\hline Ser Educacional & 34 & 120.611 & 11.357 & 131.968 & 39.428 & 11.035 & 50.463 \\
\hline Unicesumar & 7 & 13.493 & 92.874 & 106.367 & 5.282 & 55.224 & 60.506 \\
\hline Total das 10 IES & 238 & 1.522 .225 & 1.541 .914 & 3.064 .139 & 642.150 & 1.065 .188 & 1.707 .338 \\
\hline Total das outras IES & 2.000 & 2.968 .104 & 341.670 & 3.309 .774 & 912.444 & 245.490 & 1.157 .934 \\
\hline particulares & & & & & & \\
\hline
\end{tabular}

Fonte: Levantamento do autor com base nos microdados do Inep.

Observa-se que, em 2018, os 10 maiores grupos tinham 59,6\% das novas matrículas das IES privadas (presencial e EaD) e 81,9\% dos alunos matriculados em cursos de EaD. A segunda grande mudança no perfil do setor privado foi a crescente participação percentual de matrículas de IES com fins lucrativos, conforme mostra o Gráfico 4.

\section{Gráfico 4 - Percentual de matrículas e ingressantes em IES com fins lucrativos em relação à soma das IES privadas}

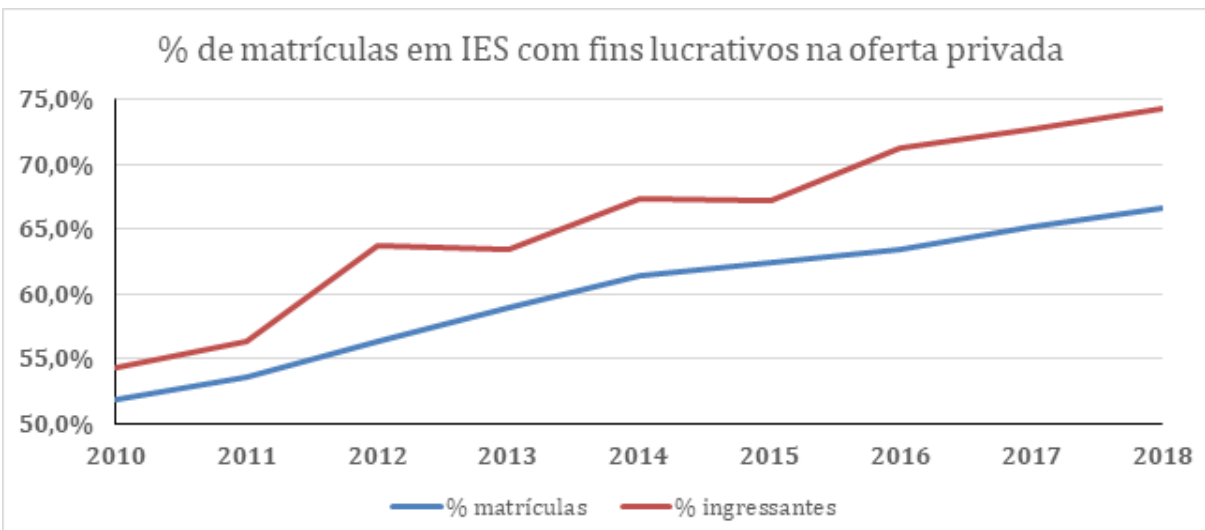

Fonte: Levantamento do autor com base nos microdados do Inep. 
Segundo o Cade (2016), em 2000, apenas 18,5\% dos alunos das IES privadas estavam matriculados em IES com fins lucrativos; em 2007 eram 27,2\%. Dos 10 grupos listados da tabela 3, apenas a Uninove é composta majoritariamente por IES sem fins lucrativos. A principal diferença entre IES com fins lucrativos e as que não têm fins lucrativos, é que as primeiras podem distribuir lucro entre proprietários ou acionistas e serem comandadas por grupos com ações na bolsa de valores, o que não é permitido para as segundas.

Essa concentração de matrículas em IES com fins lucrativos não é o que se observa de maneira geral no cenário internacional; na Europa, em particular, este é um fenômeno minoritário, sendo, inclusive, proibido em alguns países (VERHINE; LYS, 2017). Nos EUA, o último relatório anual do Departamento de Educação (U. S. DEPARTMENT OF EDUCATION, 2018) aponta que, em 2016, o número de diplomas de bacharelado das IES privadas com fins lucrativos era de apenas $6 \%$, tendo recuado a partir de 2010 após constatação de mau funcionamento. Voltaremos a este tema mais adiante.

O crescimento do número de alunos em IES com fins lucrativos no Brasil vem sendo objeto de preocupação de diferentes autores (KNOBEL; VERHINE, 2017; VERHINE; LYS, 2017; MARQUES, 2013). Em particular, o trabalho de Verhine e Lys (2017) oferece uma visão global do problema das IES com fins lucrativos, abordando diferentes aspectos, como comportamento não ético de algumas IES na captação de alunos, falta de transparência nas informações e endividamento dos estudantes.

A terceira grande mudança na oferta do ensino privado nos últimos anos é o forte aumento na proporção de matrículas em EaD, como mostra o Gráfico 5.

\section{Gráfico 5 - Percentual de matrículas e novos ingressantes na modalidade EaD das IES privadas}

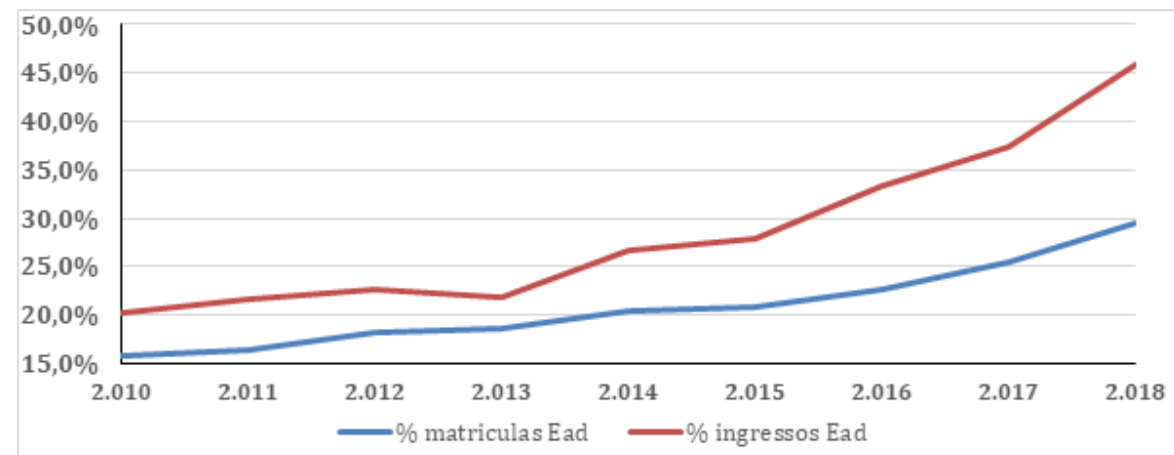

Fonte: Levantamento do autor com base nos microdados do Inep. 
Em 2018, 45,7\% dos alunos que ingressaram no ensino superior o fizeram em cursos de $\mathrm{EaD}$, fenômeno fortemente liderado pelos dez maiores grupos empresariais, cujo percentual de ingressantes em $\mathrm{EaD}$ naquele ano foi de $62,4 \%$, enquanto no restante das IES esse percentual foi de $21,2 \%$.

Esse conjunto de elementos mostra claramente que, mantida a atual tendência, os destinos do ensino superior no Brasil serão ditados pelo movimento de concentração de matrículas em grandes grupos privados com fins lucrativos e pela qualidade do trabalho de $\mathrm{EaD}$ realizado por eles. A grande questão é se esse movimento de concentração de matrículas em poucos grupos empresariais com fins lucrativos, com utilização intensiva de $\mathrm{EaD}$, é benéfico para a sociedade brasileira. Este é o ponto que abordaremos na terceira seção.

\section{RESULTADOS}

Nesta seção, apresentamos resultados para os 10 grandes grupos empresariais e demais IES privadas gerados a partir de microdados do Censo do Ensino Superior e do Enade (INEP, MICRODADOS) para as questões relacionadas à qualidade da oferta, evasão nos dois primeiros anos de curso, relação professor/aluno e custo aluno/ano.

\section{QUALIDADE DA OFERTA}

$\mathrm{O}$ que podemos inferir da qualidade educacional embutida nessa mudança de paradigma na oferta do ensino superior no país, com a concentração de matrículas em poucos grupos e utilização maciça de Educação a Distância?

Faremos esta análise a partir dos resultados dos alunos no Enade, exame que os alunos realizam ao final de seus cursos de graduação, assim como resultados do Conceito Geral de Curso e do Índice Geral de Curso (IGC), ambos gerados pelo INEP, que são os resultados de larga escala disponíveis atualmente.

Começamos olhando os dados dos formandos no Enade, analisando um ciclo completo de cursos, que se repete a cada 3 anos. O ciclo mais recente vai de 2016 a 2018. Faremos isso de duas formas:

i. calculando o percentual de alunos matriculados (em 2018) em cursos com conceito Enade 1 ou 2 nos exames de 2016 a 2018, ou seja, o percentual de alunos que estão fazendo cursos que obtiveram conceito Enade insuficiente nos três últimos exames. Para tal, somamos, inicialmente, por grupo educacional, os alunos que fizeram esses exames. Em seguida, realizamos a mesma soma apenas para alunos cujos cursos obtiveram Enade 1 ou 2, obtendo os percentuais desejados, que estão na Tabela 4. 
ii. calculando o Enade proporcional ao número de alunos de cada grupo para o conjunto de alunos que fizeram o Enade do ciclo 2016-2018. O Enade proporcional de determinada Instituição de Ensino Superior em uma modalidade (presencial ou a distância) e ano do Enade é dado por Bielschowsky (2018):

Enade proporcional (IES,Mod,ciclo Enade) $=\sum$ (anos do ciclo Enade 2015-2017) $\sum$ (cursos da Mod) Enade(IES,curso,ano)*Nparticipantes(curso,IES,a no)] / $\sum$ (cursos) Nparticipantes(curso,IES,ano)

Tabela 4 - Percentual de alunos matriculados em 2018 em cursos com

Enade 1 ou 2 das IES dos 10 maiores grupos empresariais e Enade proporcional para o ciclo 2016-2018, comparado às demais IES privadas e públicas

\begin{tabular}{|c|c|c|c|}
\hline & $\begin{array}{c}\text { Alunos em cursos Enade 1 } \\
\text { ou 2 (\%) }\end{array}$ & Enade proporcional & Total de matrículas em 2018 \\
\hline Leonardo da Vinci & 86,5 & 1,58 & 209.928 \\
\hline Kroton & 76,4 & 1,67 & 841.800 \\
\hline Ser Educacional & 56,7 & 1,87 & 131.968 \\
\hline Unip & 51,0 & 2,10 & 478.851 \\
\hline Uninove & 38,6 & 2,07 & 161.229 \\
\hline Estácio & 36,6 & 2,10 & 451.346 \\
\hline Cruzeiro do Sul & 33,9 & 2,17 & 227.602 \\
\hline Laureate & 25,0 & 2,33 & 269.468 \\
\hline Uninter & 21,5 & 2,14 & 185.580 \\
\hline Unicesumar & 8,1 & 2,53 & 106.367 \\
\hline IES dos 10 grupos & 49,1 & 2,00 & 3.064 .139 \\
\hline Demais IES privadas & 35,8 & 2,25 & 3.309 .774 \\
\hline IES públicas & 15,8 & 2,98 & 2.077 .481 \\
\hline
\end{tabular}

Fonte: Levantamento do autor com base nos microdados do Inep.

Essa tabela mostra que, enquanto 49,1\% dos alunos dos 10 grandes grupos estavam matriculados em 2018 em cursos cujo último conceito Enade (2016-2018) era insuficiente, na mesma situação estavam 36,9\% dos alunos das demais 2.000 IES particulares e apenas 15,8\% dos alunos das IES públicas. Esse é, sem dúvida, um resultado preocupante.

A tabela também mostra que os 10 maiores grupos têm um Enade proporcional de 2,0, abaixo do das demais IES privadas $(2,25)$ e das IES públicas $(2,98)$.

Em particular, a tabela mostra que mais de $50 \%$ dos alunos dos grupos Leonardo da Vinci, Kroton, Ser Educacional e Unip estavam matriculados em cursos com Enade 1 ou 2; esses grupos somam 1,66 milhão de alunos em 2018, 
representando $26,1 \%$ de todos os alunos do ensino superior privado. Por outro lado, a tabela mostra dois grupos que apresentam Enade proporcional melhor que o das demais IES privadas, que foi de 2,25: os grupos Laureate, com 2,33, e o grupo Unicesumar, com 2,53.

Para avaliar a influência da EaD nesses resultados, a Tabela 5 apresenta o percentual de alunos em cursos com Enade 1 ou 2 para os grandes grupos, com resultados apenas de quando o total de concluintes que fizeram o Enade no ciclo 2016-2018 foi superior a 1.500 alunos.

Tabela 5 - Percentual de alunos em cursos com Enade 1 ou 2 e Enade proporcional dos cursos presenciais e de EaD das IES privadas

\begin{tabular}{|c|c|c|c|c|c|}
\hline \multirow[b]{2}{*}{ Grupo empresarial } & \multicolumn{2}{|c|}{ Enade proporcional } & \multicolumn{2}{|c|}{$\begin{array}{l}\text { Alunos em cursos com } \\
\text { Enade } 1 \text { ou } 2(\%)\end{array}$} & \multirow[t]{2}{*}{$\begin{array}{c}\text { Total de } \\
\text { matrículas em } \\
2018\end{array}$} \\
\hline & Presencial & $\mathrm{EaD}$ & Presencial & $\mathrm{EaD}$ & \\
\hline Kroton & 1,91 & 1,47 & 49,7 & 98,2 & 841.800 \\
\hline Leonardo da Vinci & - & 1,58 & - & 91,9 & 209.928 \\
\hline Unip & 2,38 & 1,61 & 31,3 & 85,8 & 478.851 \\
\hline Cruzeiro do Sul & 2,21 & 2,05 & 35,9 & 27,6 & 227.602 \\
\hline Uninter & - & 2,14 & - & 21,5 & 185.580 \\
\hline Unicesumar & 2,89 & 2,37 & 0,9 & 11,3 & 106.367 \\
\hline Estácio & 2,00 & 2,39 & 44,3 & 15,6 & 451.346 \\
\hline Laureate & 2,32 & 2,42 & 25,8 & 19,4 & 269.468 \\
\hline Uninove & 1,99 & 2,43 & 45,1 & 10,5 & 161.229 \\
\hline Ser Educacional & 1,87 & - & 56,7 & - & 131.968 \\
\hline Os 10 grupos & 2,11 & 1,85 & 40,3 & 61,7 & 3.064 .139 \\
\hline $\begin{array}{c}\text { Demais IES } \\
\text { privadas }\end{array}$ & 2,27 & 1,96 & 34,2 & 55,4 & 3.309 .774 \\
\hline IES públicas & 3,03 & 2,17 & 15,5 & 52,9 & 2.077 .481 \\
\hline
\end{tabular}

Fonte: Levantamento do autor com base nos microdados do Inep.

Esta tabela mostra que os resultados da $\mathrm{EaD}$ são, em geral, piores que os dos cursos presenciais. Apresenta, em particular, desempenho muito preocupante na EaD dos grupos Kroton, Leonardo da Vinci e Unip, com 47,8\% de todas as matrículas em EaD das IES privadas em 2018. Esse não é o comportamento de todos os 10 grupos analisados, pois quatro deles - Unicesumar, Estácio, Laureate e Uninove - tiveram um Enade proporcional dos alunos de EaD do ciclo 20162018 equivalente ou mesmo melhor que aquele dos alunos presenciais das demais IES privadas, indicando que o problema do baixo desempenho dos alunos de $\mathrm{EaD}$ no Enade de alguns grupos educacionais não é uma característica intrínseca 
da modalidade da educação a distância, assunto que já abordamos anteriormente (BIELSCHOWSKY, 2018). A questão da qualidade na oferta de EaD será discutida em maior detalhe na quarta seção do presente trabalho.

Aparentemente, os grupos com piores resultados na $\mathrm{EaD}$ influenciam mais em cursos com grande demanda; o Gráfico 6 mostra os resultados do Enade de Pedagogia de 2017 para as 10 maiores ofertas de EaD desse curso.

\section{Gráfico 6 - Enade 2017 do curso de Pedagogia com EaD para as 10 IES com maior número de alunos}

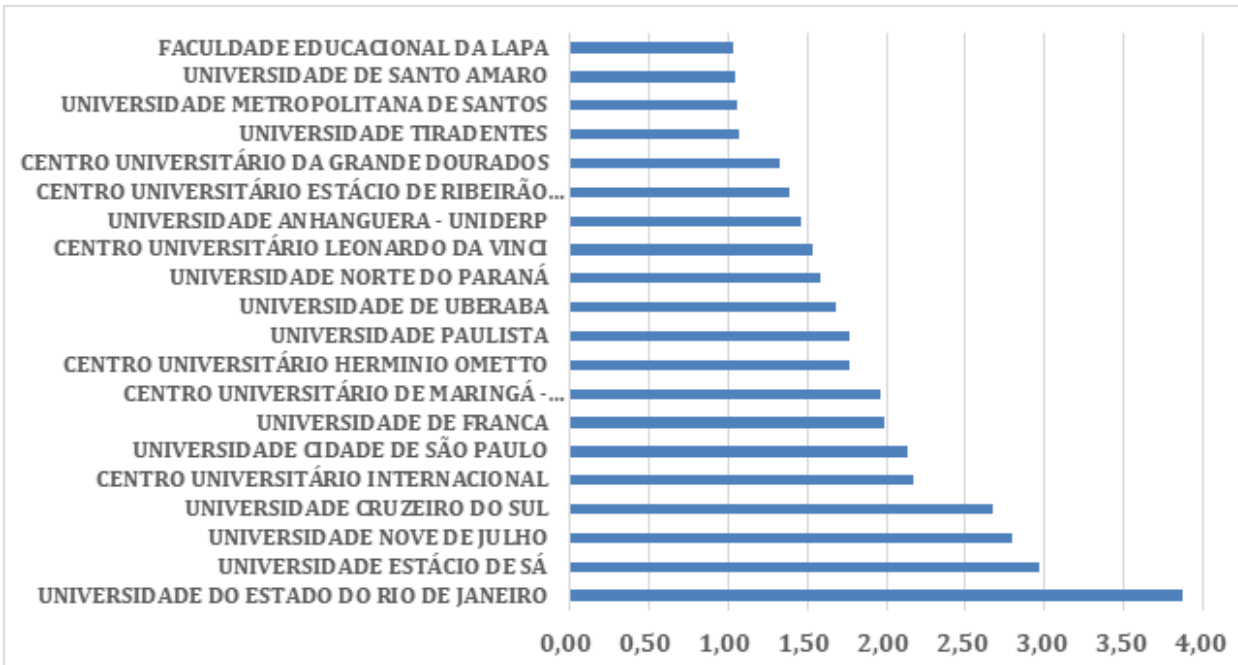

Fonte: Bielschowsky (2018).

Em 2017, nove IES tiveram resultados no Enade inferior a 1,6 em cursos de Pedagogia com EaD, somando 203.602 mil alunos matriculados, o que representava cerca de 30\% de todos os alunos de Pedagogia do país nas duas modalidades (661.034 alunos). Cabe ainda chamar a atenção de que 37.517 alunos de Pedagogia com EaD estão matriculados em quatro IES com Enade em 2017 inferior a 1,1 .

No Enade de 2018, o curso de Serviço Social da Unip, com 20 mil alunos matriculados, obteve nota de apenas 0,83 , um resultado jamais alcançado por um curso com tamanho número de alunos.

É comum as IES divulgarem os resultados oferecidos pelo Inep para o Conceito Provisório de Curso (CPC) ou para o Conceito Geral de Curso (CGC), sem mencionar seus resultados no Enade. O CPC de um curso tem quatro dimensões: $20 \%$ é a nota do Enade, 35\% é a nota do Indicador de Diferença entre 
os Desempenhos Observado e Esperado (NIDD), 30\% referem-se ao percentual de mestres, doutores e regime de trabalho dos docentes e $15 \%$ referem-se à opinião dos alunos sobre as condições do processo formativo.

Mostramos anteriormente que esse índice não funciona para cursos de EaD com grande número de alunos e baixo conceito Enade (BIELSCHOWSKY, 2018), pois a dimensão do corpo docente (30\% do CPC) não considera a relação alunos/professor, o Indicador de Diferença de Desempenho (IDD) (35\% do (PC) não funciona para cursos de EaD com baixo conceito Enade e os estudantes avaliam seus cursos (15\% do CPC), de maneira geral, de forma generosa.

Outro indicador importante utilizado pelo MEC é o Conceito Geral de Cursos (INEP, 2018), que leva em conta a média do CPC do último triênio, a média dos conceitos de avaliação da Capes e a distribuição de estudantes entre os diferentes níveis de ensino. A Tabela 6 compara, para o ciclo 2016-2018 e para as IES com maior número de matrículas, os resultados para o Enade proporcional (BIELSCHOWSKY, 2018) juntamente à média do CPC ponderada pelo número de alunos dos cursos avaliados, que é utilizada pelo Inep no cálculo do Índice Geral de Curso - IGC, e o valor do IGC calculado pelo Inep (2018).

\section{Tabela 6 - Comparação entre os resultados do Enade, CPC e CGC de algumas IES para o ciclo 2016-2018}

\begin{tabular}{|c|c|c|c|c|}
\hline IES & IGC contínuo & IGC faixa & $\begin{array}{c}\text { CPC } \\
\text { proporcional } \\
\text { ao número de } \\
\text { alunos }\end{array}$ & $\begin{array}{c}\text { Enade } \\
\text { proporcional }\end{array}$ \\
\hline Universidade Paulista & & 3 & 2,66 & 2,10 \\
\hline Universidade Pitágoras Unopar & 2,48 & 3 & 2,47 & 1,44 \\
\hline Universidade Estácio de Sá & 2,70 & 3 & 2,68 & 2,25 \\
\hline Centro Universitário Leonardo Da Vinci & 2,85 & 3 & 2,84 & 1,64 \\
\hline Universidade Nove de Julho & 3,03 & 4 & 3,00 & 2,07 \\
\hline Centro Universitário Internacional & 2,99 & 4 & 2,99 & 2,14 \\
\hline Universidade Anhanguera & 2,24 & 3 & 2,23 & 1,47 \\
\hline Centro Universitário de Maringá - Unicesumar & 2,95 & 4 & 2,94 & 2,53 \\
\hline Centro Univ. das Faculdades Metrop. Unidas & 2,65 & 3 & 2,65 & 2,51 \\
\hline Universidade Cidade de São Paulo & 2,96 & 4 & 2,94 & 2,00 \\
\hline Universidade Anhembi Morumbi & 3,08 & 4 & 3,04 & 2,81 \\
\hline Universidade Cruzeiro do Sul & 3,12 & 4 & 3,10 & 2,17 \\
\hline Universidade Federal Fluminense & 3,55 & 4 & 3,08 & 3,27 \\
\hline
\end{tabular}

Fonte: Levantamento do autor com base nos microdados do Inep. 
É grave a diferença entre o CGC e os resultados dos alunos no Enade (Enade proporcional), sendo que é o CGC que deslancha o processo de supervisão. Todas as IES consideradas na Tabela 6 têm CGC (faixa) de 3 ou 4, o que poderia ser considerado satisfatório ou bom, mesmo em casos em que o Enade proporcional para o ciclo 2016-2018 esteve em torno de 1,5, como foram os casos da Unopar e do Centro Leonardo da Vinci.

Diante dessas incertezas com relação à metodologia adotada para gerar os índices que medem a qualidade da educação superior no Brasil, analisaremos as notas brutas dos alunos no Enade. Optamos por analisar o curso de Serviço Social por ter resultados recentes, do Enade de 2018, e ser alvo preferencial dos maiores grupos, que tinham $57 \%$ de todos os alunos matriculados nas IES públicas e privadas em 2018. A Tabela 7 mostra o número de alunos matriculados no curso de Serviço Social em 2018 e o número de alunos que realizaram o Enade de 2018. Destacamos o curso de Serviço Social em EaD da Unip por ter obtido um conceito Enade de apenas 0,83 em 2018 com 20.495 alunos matriculados, cerca de $15 \%$ de todos os alunos do curso de Serviço Social.

\section{Tabela 7 - Alunos matriculados em 2018 e alunos que realizaram o Enade de 2018}

\begin{tabular}{|c|c|c|c|}
\hline & $\begin{array}{c}\text { Alunos matriculados em } \\
\mathbf{2 0 1 8}\end{array}$ & $\begin{array}{c}\text { Alunos matriculados em } \\
\mathbf{2 0 1 8}(\%)\end{array}$ & $\begin{array}{c}\text { Alunos que fizeram o Enade } \\
\text { em 2018 }\end{array}$ \\
\hline IES públicas & 17.019 & $12,3 \%$ & 3.538 \\
\hline Os 10 grupos & 90.904 & $65,5 \%$ & 12.878 \\
\hline Outras IES privadas & 30.825 & $22,2 \%$ & 5.799 \\
\hline Total & 138.748 & $100,0 \%$ & 24.601 \\
\hline Unip EaD & 20.494 & $14,8 \%$ & 2.386 \\
\hline
\end{tabular}

Fonte: Levantamento do autor com base nos microdados do Inep.

Comparamos o perfil de notas do componente específico do Enade para os 24.601 alunos que fizeram o Enade dos cursos de Serviço Social em 2018, pois ilustra aquilo que os alunos adquiriram no curso e levam para sua vida profissional. Esta nota é a média ponderada da parte objetiva com 27 questões (85\%) e discursiva com 3 questões (15\%) no componente específico do exame Enade 2018 do curso de serviço social.

O gráfico 7 mostra o perfil de notas dos 10 maiores grupos privados, das demais IES privadas, das IES públicas e do curso de serviço social de EaD da UNIP. Para obter este gráfico, dividimos o resultado dos alunos na parte específica em 20 intervalos, com intervalo de notas de 0 a 5 , de 5 a 10, de 10 a 15 
e assim por diante, até o intervalo de 95 à 100, e ajustamos um polinômio de 50 grau a estes dados, obtendo um acordo neste ajuste superior a 95\% para o desvio quadrático médio.

\section{Gráfico 7 - Perfil de notas da parte específica do Enade 2018 para o curso de Serviço Social}

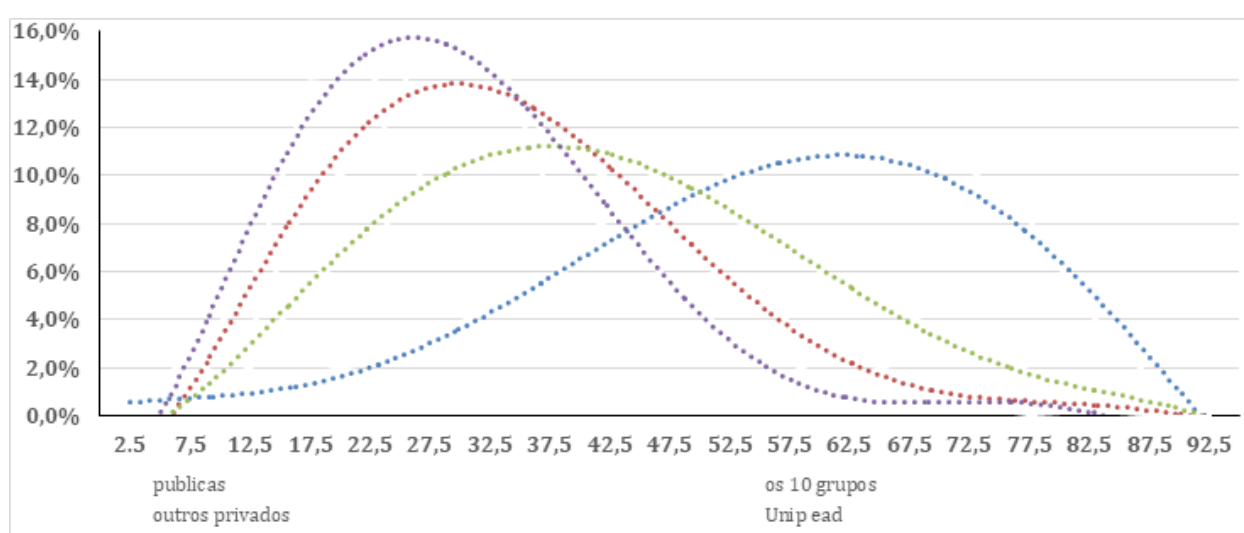

Fonte: Levantamento do autor com base nos microdados do Inep.

Esse gráfico mostra a grande distância do resultado da parte específica do Enade 2018 entre os alunos das universidades públicas e os dos grupos privados. É um quadro ainda mais preocupante para os alunos dos 10 grandes grupos empresariais que detinham $65 \%$ dos alunos de Serviço Social de todo o país em 2018. O gráfico mostra, em particular, um quadro dramático para os alunos que se diplomam em Serviço Social na EaD da Unip, com uma nota média de apenas 30,3 em 100, com 200 alunos que tiraram notas na parte específica menor que 10 em 100. Cabe uma investigação das consequências para a sociedade o fato de a Unip colocar por ano no mercado de trabalho 200 profissionais que acertaram menos de $10 \%$ das questões na área específica de sua área de sua formação no Enade.

Uma justificativa incorreta que se tem utilizado para esses resultados é de que os alunos de IES com pior desempenho pertencem às classes sociais menos favorecidas. Os microdados do Enade de 2018 têm informações sobre a renda familiar dos alunos do curso de Serviço Social, que reunimos na Tabela 8. 
Tabela 8 - Renda familiar dos formandos de Serviço Social que realizaram o Enade em 2018

\begin{tabular}{|c|c|c|c|c|c|c|}
\hline & $\begin{array}{c}\text { <1,5 salário } \\
\text { mínimo (\%) }\end{array}$ & $\begin{array}{c}\text { De 1,5 a 3 } \\
\text { salários } \\
\text { mínimos (\%) }\end{array}$ & $\begin{array}{c}\text { De 3 a 4,5 } \\
\text { salários } \\
\text { mínimos (\%) }\end{array}$ & $\begin{array}{c}\text { De 4,5 a 6 } \\
\text { salários } \\
\text { mínimos (\%) }\end{array}$ & $\begin{array}{c}\text { De 6 a 10 } \\
\text { salários } \\
\text { mínimos (\%) }\end{array}$ & $\begin{array}{c}>\text { 10 salários } \\
\text { mínimos (\%) }\end{array}$ \\
\hline IES públicas & $37,2 \%$ & $30,8 \%$ & $17,4 \%$ & $6,7 \%$ & $5,9 \%$ & 2,0 \\
\hline $\begin{array}{c}\text { Os 10 grupos } \\
\text { empresariais }\end{array}$ & $38,6 \%$ & $35,3 \%$ & $16,3 \%$ & $5,2 \%$ & $3,7 \%$ & $1,0 \%$ \\
\hline $\begin{array}{c}\text { Outras IES } \\
\text { privadas }\end{array}$ & $38,1 \%$ & $35,0 \%$ & $16,8 \%$ & $5,6 \%$ & $3,7 \%$ & $0,8 \%$ \\
\hline Unip EaD & $37,78 \%$ & $34,9 \%$ & $16,6 \%$ & $5,5 \%$ & $4,0 \%$ & $1,2 \%$ \\
\hline
\end{tabular}

Fonte: Levantamento do autor com base nos microdados do Inep.

Esses resultados mostram que o perfil de renda dos alunos do curso de Serviço Social que realizaram o Enade de 2018 é muito parecido, e não explica, em termos de renda, as marcantes diferenças entre os resultados alcançados por esses alunos na prova específica.

\section{EVASÃO DOS ALUNOS NOS PRIMEIROS DOIS ANOS}

O senado dos EUA (UNITED STATES SENATE, 2012) destacou, em um relatório em que analisa a oferta de educação superior das IES com fins lucrativos entre os anos de 2006 e 2010, a utilização por parte dessas IES, de uma estratégia agressiva de captação de alunos, pouco conectada com interesses acadêmicos, e que esses alunos evadiam nos primeiros dois anos - bem mais que o restante dos alunos do ensino superior daquele país. Avaliamos se algo parecido está ocorrendo no Brasil, ou seja, se os alunos dos grandes grupos têm maiores taxas de evasão nos dois primeiros anos de curso.

Para tal, calculamos, com base nos microdados do ensino superior de 2017 e 2018, o número de alunos que abandonaram o curso em 2017 e 2018 (campo TP_SITUACAO=4) dentre os alunos que ingressaram em 2017 (campo NU_ANO_INGRESSO=2017). Determinamos também o percentual de alunos ativos, formados e com matrícula trancada no final de 2018 dentre os que ingressaram em 2017, como mostra a Tabela 9. 
Tabela 9 - Evasão no final de 2018 para os alunos que ingressaram em 2017

\begin{tabular}{|c|c|}
\hline Grupo & $\begin{array}{c}\text { Alunos que entraram em 2017 e foram desligados dos } \\
\text { cursos em 2017 e 2018 (\%) }\end{array}$ \\
\hline Kroton & 59,8 \\
\hline Unip & 50,5 \\
\hline Cruzeiro do Sul & 44,7 \\
\hline Ser Educacional & 42,1 \\
\hline Unicesumar & 39,0 \\
\hline Laureate & 35,8 \\
\hline Leonardo da Vinci & 33,7 \\
\hline Uninter & 28,0 \\
\hline Estácio & 24,2 \\
\hline Uninove & 22,0 \\
\hline Os 10 grupos & 44,0 \\
\hline Outras IES privadas & $\mathbf{2 7 , 1}$ \\
\hline IES públicas & $\mathbf{2 2 , 5}$ \\
\hline
\end{tabular}

Fonte: Levantamento do autor com base nos microdados do Inep.

A Tabela 9 mostra uma grande diferença entre o percentual de 44,0\% de alunos desligados nos primeiros dois anos de curso dos 10 grandes grupos e os $27,1 \%$ das demais IES privadas e $22,5 \%$ das IES públicas, um resultado preocupante, que merece intensa investigação por parte do MEC.

Essa tabela apresenta um quadro dramático para os alunos do grupo Kroton e do grupo Unip, que somam 1,32 milhão de matrículas em 2018 (20,7\% de todos os alunos das IES privadas), pois mais da metade de seus alunos evadem durante os primeiros dois anos. Há de se avaliar o perfil socioeconômico desses evadidos; provavelmente não são das camadas mais favorecidas. São pessoas com forte impacto emocional e financeiro, por terem desperdiçado tempo e dinheiro - muitas vezes contraindo dívidas financeiras.

Se considerarmos no cálculo da evasão também os alunos trancados, o quadro fica ainda pior: após dois anos de curso, 55,6\% dos alunos dos grandes grupos estavam desligados ou com matrícula trancada, contra $37,6 \%$ das demais IES privadas e $29,5 \%$ das públicas, ou seja, mais da metade dos alunos que ingressaram em 2017 nos dez grandes grupos privados não estavam ativos ou formados no final de 2018. 
Mostramos em trabalhos anteriores que a taxa de evasão depende criticamente da carreira (BIELSCHOWSKY; MASUDA, 2017). Para verificar se esse comportamento ocorria também na análise de apenas uma carreira, obtivemos os resultados equivalentes para o curso de Pedagogia, observando comportamento parecido.

Aparentemente, alguns grupos empresariais estão utilizando uma estratégia de captação de alunos que guarda semelhança com as preocupações apontadas no relatório do Senado Norte-Americano. Outro indício dessa prática é que algumas IES captam alunos continuamente, ao longo de todo o ano, e não apenas uma ou duas vezes por ano, com campanhas maciças na grande mídia e valores baixos de matrícula para os primeiros meses.

\section{IMPACTO NO TRABALHO DOS PROFISSIONAIS DE EDUCAÇÃO SUPERIOR E APOIO AO ESTUDANTE}

O Censo da Educação Superior disponibiliza apenas o total de professores de uma IES, não identificando seu número total de horas trabalhadas nem correlacionando o quadro docente com os cursos que a IES oferece. Tampouco oferece uma visão do quadro de tutores que atuam nos cursos de EaD. Nesse sentido, não dispomos de dados suficientemente precisos para um estudo mais aprofundado do trabalho docente em diferentes IES. Podemos, entretanto, relacionar a proporção aluno/professor ao percentual de alunos de $\mathrm{EaD}$ de cada grupo educacional, resultado que apresentamos na Tabela 10.

\section{Tabela 10 - Relação alunos/professor como função do percentual de alunos matriculados em $\mathrm{EaD}$}

\begin{tabular}{|c|c|c|}
\hline Grupo & Matrículas em EaD das IES (\%) & Alunos por professor \\
\hline Ser Educacional & 8,6 & 41 \\
\hline Laureate & 16,1 & 45 \\
\hline Uninove & 21,2 & 67 \\
\hline Estácio & 36,2 & 62 \\
\hline Unip & 46,8 & 58 \\
\hline Cruzeiro do Sul & 49,6 & 70 \\
\hline Kroton & 56,1 & 75 \\
\hline Unicesumar & 87,3 & 140 \\
\hline Leonardo da Vinci & 97,1 & 422 \\
\hline Uninter & 98,4 & 460 \\
\hline
\end{tabular}

Fonte: Levantamento do autor com base nos microdados do Inep. 
Essa tabela mostra, como já era de se esperar, clara relação entre o número de docentes e o percentual de alunos de $\mathrm{EaD}$ no total de alunos das IES desses grupos, com impacto direto no custo aluno/ano dessas instituições. Estimamos, com base no Censo da Educação Superior de 2018 (INEP, s/d), que cerca de $40 \%$ do custo das IES particulares devem-se ao pagamento de salários e encargos de docentes, necessários tanto nos cursos presenciais como nos cursos em $\mathrm{EaD}$, neste caso com o apoio de tutores.

Um curso de EaD de qualidade necessita de forte apoio aos estudantes, de preferência com utilização de metodologias ativas no processo de ensinoaprendizagem, o que demanda ainda mais apoio de professores e tutores. Além disso, é necessário um consistente processo de avaliação dos estudantes, o que demanda forte trabalho do corpo docente. Mas, sendo o salário desses professores o maior elemento dos custos, aparentemente, parte das IES trabalha de forma deficitária nessa questão, conquistando com isso vantagens competitivas.

A carência de professores, além de afetar a qualidade do curso que é oferecido, impacta negativamente no trabalho dos profissionais da Educação, reduzindo o mercado de trabalho desses profissionais. Por outro lado, o número insuficiente de professores qualificados na oferta de $\mathrm{EaD}$ de algumas IES não impacta o Conceito Provisório de Cursos (CPC), uma vez que esse índice não leva em conta a relação aluno/professor, apenas a qualificação e o regime de trabalho dos docentes cadastrados; como consequência, também não impacta o Conceito Geral de Cursos (CGC).

\section{CUSTO ALUNO/ANO DE CADA IES}

Estudamos o custo aluno/ano dos diferentes grupos e sua relação com o percentual de matrículas em EaD desses grupos. Utilizamos a metodologia e parte dos resultados do custo aluno/ano de um trabalho em andamento (AMARAL E BIELSCHOWSKY, 2020). Nesta pesquisa, calculamos o custo aluno/ano com base nos custos totais anuais das IES declarados no Censo da Educação Superior divididos pelo número de alunos. Uma vez que esses resultados, em alguns casos, apresentam-se inconsistentes para alguns anos, consideramos a média dos dois valores de custo anual dos anos de 2015 a 2018 corrigida pelo IPCA. Algumas mantenedoras declaram, no Censo, o somatório das despesas de todas as suas IES, ao invés do valor para cada IES. Nesses casos, consideramos o custo anual de uma IES como proporcional ao seu número de alunos com relação ao total de alunos das mantidas. Na Tabela 11 mostramos o custo aluno/ano das IES desses 10 grupos empresariais e das demais IES como função do percentual de alunos de $\mathrm{EaD}$. 
Tabela 11 - Custo aluno/ano por grupo educacional e percentual de alunos em EaD

\begin{tabular}{|c|c|c|c|}
\hline Grupo & \% alunos EaD & Custo aluno/ano & $\begin{array}{c}\text { Número de alunos } \\
\text { matriculados em 2018 }\end{array}$ \\
\hline Uninter & 98,4 & $2.401,00$ & 185.580 \\
\hline Leonardo da Vinci & 97,6 & $1.336,00$ & 208.919 \\
\hline Unicesumar & 87,3 & $4.339,00$ & 106.367 \\
\hline Kroton & 56,3 & $6.015,00$ & 840.266 \\
\hline Cruzeiro do Sul & 49,6 & $6.467,00$ & 227.599 \\
\hline Unip & 46,8 & $5.434,00$ & 478.851 \\
\hline Estácio & 36,2 & $6.345,00$ & 451.346 \\
\hline Uninove & 21,2 & $6.414,00$ & 161.229 \\
\hline Laureate & 16,2 & $8.567,00$ & 268.935 \\
\hline Ser Educacional & 8,6 & $9.930,00$ & 131.968 \\
\hline Os 10 grupos & 50,3 & $6.518,00$ & 3.065 .687 \\
\hline Demais IES particulares & 10,3 & $12.591,00$ & 3.316 .358 \\
\hline
\end{tabular}

Fonte: Amaral; Bielschowsky (2020).

Essa tabela mostra um resultado esperado: grupos com maior número percentual de alunos de $\mathrm{EaD}$ apresentam menores custos aluno/ano. Mostra, em particular, que o custo médio aluno/ano dos 10 maiores grupos privados é quase a metade daquele das demais IES particulares, caracterizando um modelo de negócios que favorece a concentração de matrículas em poucos grupos.

Souza et al. (2017) estudaram a lucratividade da Kroton em seus três segmentos principais - a educação básica, o ensino superior presencial e o ensino superior a distância; reproduzimos a seguir o Gráfico 4 daquele trabalho, como nosso Gráfico 8.

\section{Gráfico 8 - Margem bruta (MB) por segmentos operacionais da Kroton}

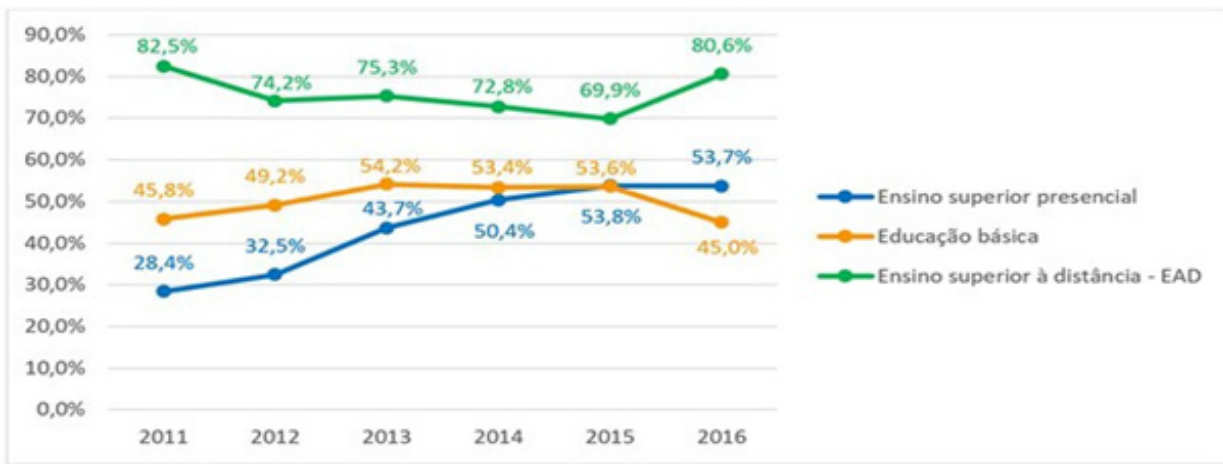

Fonte: Souza; Mendonça; Silva; Benedicto (2017). 
Este trabalho traz um importante resultado: mostra maior lucratividade do grupo Kroton no setor de EaD, quando comparado com seu ensino presencial. Ou seja, não apenas o custo aluno/ano é menor com os alunos de $\mathrm{EaD}$ quando comparamos diferentes grupos, como também o lucro da empresa Kroton é maior no setor de EaD.

$\mathrm{O}$ menor custo dos cursos de $\mathrm{EaD}$ poderia ser um fator positivo no processo de democratização do acesso ao ensino superior, caso a oferta estivesse controlada do ponto de vista da qualidade. Não se tendo maior controle da qualidade da oferta, com o crescente processo de desregulamentação da EaD e a interrupção da supervisão, conforme discutiremos a seguir, o menor custo aluno/ ano da $\mathrm{EaD}$ pode contribuir para a concentração de matrículas em poucos grupos que praticam uma $\mathrm{EaD}$ de baixa qualidade.

\section{BREVE HISTÓRICO DA REGULAÇÃO E SUPERVISÃO DA EDUCAÇÃO A DISTÂNCIA NO BRASIL}

No Brasil, a educação superior a distância começou em 1995, com o curso de licenciatura plena para professores em exercício em Educação Básica de $1^{\text {a a }} 4^{\mathrm{a}}$ séries da Universidade Federal de Mato Grosso (UFMT) e da Universidade do Estado de Mato Grosso (Unemat) (NEDER, 2004), exemplo que foi seguido por diversas IES. Esse início de oferta, calcada no Art. 80 da Lei no 9.394, de Diretrizes e Bases da Educação (LDB) de 1996, gerou uma discussão no MEC sobre EaD, resultando nos Referenciais de Qualidade para oferta de EaD (MEC, 2003; 2007). O primeiro vestibular não dirigido especificamente a professores em exercício da Educação Básica foi realizado em 2003 pelo consórcio Cederj, das universidades públicas do Rio de Janeiro (BIELSCHOWSKY, 2017). O Gráfico 9 apresenta a evolução de matrículas de EaD no país. 


\section{Gráfico 9 - Evolução das matrículas em EaD de instituições públicas e privadas desde 2000}

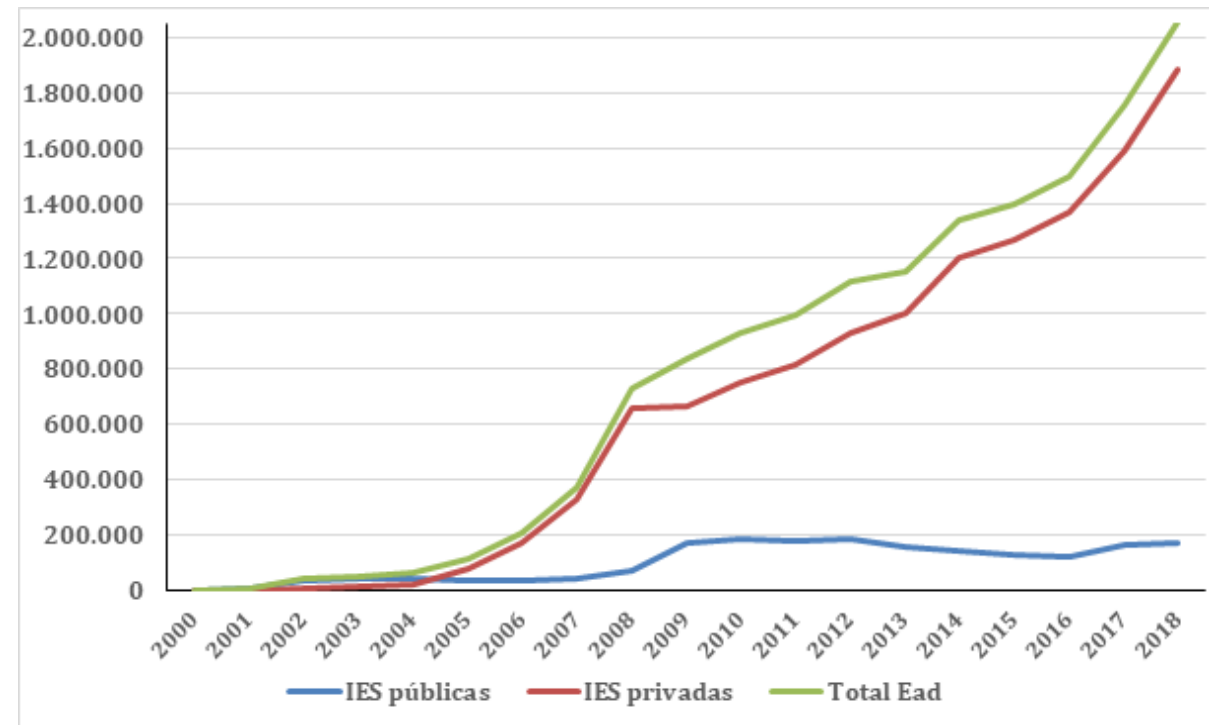

Fonte: Microdados do Inep

O gráfico mostra uma "explosão" no número de matrículas em EaD do setor privado entre 2005 e 2007, que lamentavelmente foi parcialmente calcada em uma oferta de baixa qualidade, gerando um esforço do MEC em processos de acreditação em EaD, com a revisão dos Referenciais de Qualidade para oferta de $\mathrm{EaD}$ (MEC, 2007), os Decretos $\mathrm{n}^{\circ} 5.622 / 05, \mathrm{n}^{\circ} 5.773 / 06$, que regulamentaram o Art. 80 da LDB, do Decreto $n^{\circ}$ 6.303/07, que estabelece a exigência de polos regionais, a Portaria Normativa $\mathrm{n}^{\circ} 40$, que institui o e-MEC, bem como instrumentos específicos para $\mathrm{EaD}$ no Inep de autorização de IES para $\mathrm{EaD}$, autorização e reconhecimento de cursos de $\mathrm{EaD}$ e autorização da criação de polos. Esse comportamento também resultou, naquele período, em intenso processo de supervisão, realizado pela Secretaria de Educação a Distância (SEED) do MEC entre 2007 e 2010.

Com o auxílio de cerca de 400 professores das nossas universidades que visitaram essas IES e seus polos, e uma equipe estruturada na SEED/MEC, cada IES que apresentava indícios de problemas de oferta foi minuciosamente avaliada. Foram estabelecidos, quando necessário, termos de saneamento detalhados com caminhos para a qualificação da sua oferta de EaD. Esse trabalho, que resultou 
no descredenciamento de várias IES e de milhares de polos de apoio regionais, mostrou as seguintes fragilidades da oferta de EaD daquelas IES indicadas para o saneamento:

- Desconexão da universidade com os alunos: atividades acadêmicas terceirizadas, às vezes mesmo por um terceirizado do terceirizado;

- Alguns cursos não eram, na prática, cursos de graduação:

i. O material didático não tinha densidade para um curso de graduação; havia disciplinas com 40 páginas de material impresso e pouco ou nenhum material complementar;

ii. A avaliação era realizada nesse contexto de conteúdo, ou seja, não exigia do estudante conhecimentos compatíveis com um curso de graduação;

- Avaliações desconectadas dos docentes das universidades. Por exemplo, provas objetivas corrigidas automaticamente, em cima de um conteúdo aligeirado. Alunos com deficiências graves de escrita formando-se em carreiras como Pedagogia ou licenciatura em Letras;

- Falta de apoio ao estudante: encontramos casos em que o estudante não dispunha de tutoria presencial e a tutoria a distância era quase inexistente;

- Polos de apoio presencial sem adequação mínima para oferta de educação superior.

Em nosso entendimento, o mecanismo mais preocupante da oferta de $\mathrm{EaD}$ daquele período foram cursos com conteúdo superficial ao extremo, sendo os alunos avaliados nesses conteúdos, ou seja, não adquirindo conhecimentos minimamente compatíveis com o ensino superior. Encontramos casos em que o material impresso de uma disciplina de graduação, que correspondia a 60 horas em um curso presencial, estava contido em 20 páginas de espaço duplo no material impresso, sem quaisquer complementos de conteúdo no espaço virtual ou em outros materiais e os alunos eram avaliados no contexto apenas do conteúdo dessas 20 páginas.

O efeito imediato desse trabalho de supervisão foi interromper o crescimento desordenado da oferta pelo setor privado, como mostra o comportamento do número de alunos de EaD em 2008 e 2009 no Gráfico 9, com a interrupção do ciclo de crescimento exponencial de matrículas do setor privado, fruto do descredenciamento de várias IES para a oferta de EaD e a requalificação com restrição ao crescimento de matrículas de outras.

Lamentavelmente, o processo de supervisão no MEC foi interrompido a partir de 2011, e os instrumentos de avaliação do Inep foram modificados, retirando parte dos cuidados relacionados especificamente com a EaD (colocados anteriormente). Recentemente, os processos regulatórios foram modificados (Decretos no $9.235 / 17$ e 9.057/17 e Portaria MEC n ${ }^{\circ} 11 / 2017$ ), permitindo a 
criação de novos polos sem vistoria prévia e abrindo brechas para o credenciamento de IES sem prévia análise pelo Ministério da Educação, como mostra o Art. 12 e seu $\ 2^{\circ}$ da Portaria MEC no 11/2017.

O Gráfico 9 mostra o crescimento do número de alunos de EaD nos últimos 4 anos, semelhantemente ao período de 2005 a 2007. Além de um crescimento percentual de matrículas parecido, esses dois períodos guardam duas outras similaridades: crescente concentração de matrículas em poucas IES e claros indícios de baixa qualidade na oferta de EaD dessas IES, que detêm grande número de alunos (BIELSCHOWSKY, 2018).

\section{SÍNTESE DAS TENDÊNCIAS DO ENSINO SUPERIOR PRIVADO NO BRASIL}

Resumimos abaixo os principais resultados deste trabalho:

\section{A. Movimento de concentração de matrículas em poucos grupos privados}

1. Estamos diante de uma crescente concentração de matrículas em poucos grupos privados: hoje quase metade das matrículas do ensino superior privado está nas mãos de 10 grandes grupos empresariais, 9 dos quais com fins lucrativos, que tiveram em 2018 cerca de 60\% de todos os novos ingressos no ensino superior particular;

2. O percentual de alunos matriculados e de novos ingressos em IES com fins lucrativos no setor privado continua crescendo, respondendo em 2018 por $75 \%$ de todas as novas matrículas do setor privado;

3. Os maiores grupos privados tendem a transformar matrículas do ensino presencial em Educação a Distância; a estimativa é de que, em 2019, metade de todas as novas matrículas das IES privadas tenham sido em EaD;

4. O custo aluno/ano dos grupos com mais alunos em EaD tende a ser inferior àquele de grupos com menos alunos em EaD. Aparentemente, as IES que crescentemente concentram seus alunos em EaD conseguem atraí-los com preços menores ao comprimir os custos de $\mathrm{EaD}$ ao limite, algumas com pouquíssimos professores e tutores por aluno, provavelmente com conteúdo rebaixado e insuficiente regulação do Estado brasileiro sobre a qualidade da formação desses alunos; 
5. Não existem, no MEC, quaisquer ações mais consistentes para coibir a atuação de grupos econômicos cujas IES apresentam baixo desempenho no Enade e índices de evasão excessivos. Esse nos parece um fator determinante na forma acelerada como se dá a atual concentração de matrículas em poucos grupos com as características descritas no item anterior.

\section{B. Consequências da concentração de matrículas em poucos grupos privados}

1. A qualidade do ensino superior, a julgar pelos resultados dos alunos no Enade, está caindo com esse movimento de concentração de matrículas, uma vez que, no ciclo 2016-2018, 49,1\% de todos os alunos matriculados nos 10 grandes grupos privados (presencial e em EaD) estavam em cursos com Enade insuficiente (1 ou 2), contra 35,8\% das demais IES privadas e 15,8\% das públicas;

2. Uma primeira análise das notas da prova específica do Enade do curso de Serviço Social mostra um pior desempenho das IES dos 10 grupos empresariais que o das demais IES, com um resultado extremamente preocupante para os alunos do curso de EaD da Unip, que representa cerca de 15\% das matrículas desse curso em 2018;

3. A concentração de matrículas em poucos grupos implica taxas de evasão significativamente maiores; a evasão nesses grandes grupos privados nos dois primeiros anos é de $44,0 \%$, comparada com $27,1 \%$ das demais IES privadas e $22,5 \%$ das IES públicas. Se incluirmos no cálculo dos evadidos os alunos com matrícula trancada, a evasão dos grandes grupos nos dois primeiros anos vai para 55,6\%, comparada com $37,6 \%$ das demais IES privadas e $29,5 \%$ das IES públicas;

4. O movimento de concentração de matrículas em poucos grupos empresariais leva a uma relação aluno/professor significativamente maior que a das demais IES privadas, prejudicando de maneira geral a qualidade do ensino das IES desses grupos;

5. Uma possível justificativa para essa reorganização do setor privado poderia estar relacionada a um aumento significativo do número de alunos matriculados, contribuindo para a democratização do acesso ao ensino superior, o que não ocorreu entre 2014 e 2017, em que o total de matrículas ficou estagnado, apresentando em 2018 pequeno crescimento. Por outro lado, uma vez que as taxas de evasão dos alunos nos primeiros dois anos nos grandes grupos privados 
são significativamente maiores que as das demais IES particulares, estimamos que o efeito final no número de diplomados decorrente dessa reorganização do setor privado pode ser negativo, ao invés de positivo.

Esses resultados mostram que o movimento de concentração de matrículas em poucos grupos não é positivo para o país, indicando a necessidade de maior intervenção do Estado. $\mathrm{O}$ atual ministro da Educação, Sr. Weintraub, tem advogado exatamente o contrário, ou seja, uma ainda menor interferência do Estado na oferta, conforme mostra um trecho de sua fala na abertura do $21 \mathrm{o}$ Fórum Nacional do Ensino Superior Particular na quinta-feira, dia 26 de setembro de 2019, em São Paulo (MEC, 2019): “A supervisão do Estado é mantida. O setor se autorregula e o Estado fiscaliza e observa se está funcionando adequadamente. Isso já tem em várias áreas da economia. Você permite maior liberdade com responsabilidade [...]. É uma mudança cultural muito grande".

Essa também é a posição de alguns setores comprometidos com esses grandes grupos, como a Associação Nacional de Universidades - Anup, que agrega os principais grupos empresariais mencionados e foi criada para concorrer com a tradicional Associação Brasileira de Mantenedores - ABM, que reúne a grande maioria das IES privadas. A presidente da Anup, Sra. Elizabeth Guedes ${ }^{1}$ (CNE, 2019) defende, em princípio, a autorregulação, apesar de reconhecer que em âmbito mundial "não encontramos a autorregulação do ensino superior na amplitude do que vem sendo discutido/pretendido no Brasil, não existe isso em lugar nenhum. Há casos de entes privados que assumiram parcelas relevantes da atividade autorregulatória, mas não é uma autorregulação plena como se pretende aqui".

De fato, essa não é uma tendência internacional; não é, por exemplo, o que ocorre na Europa ou nos EUA. Essas e outras afirmações do gênero trazem sempre o exemplo dos EUA, que têm agencias de acreditação privadas credenciadas pelo governo, as quais foram muito criticadas ao serem constatados abusos na oferta desses grupos com fins lucrativos, após um período de crescimento acentuado entre 2006 e 2010. Ocorreu, naquele país, forte movimento de resistência da academia e do governo, tendo o Senado Norte-Americano (UNITED STATES SENATE, 2012) conduzido uma extensa investigação de dois anos, conhecida como "Harkin report", que teve como resultado concreto o encolhimento percentual da oferta das IES com fins lucrativos. Entre as deficiências apontadas no relatório, encontramos várias que parecem se aplicar ao atual momento do ensino superior privado brasileiro. Estas são algumas conclusões daquele relatório:

1 A Sra. Elizabeth Guedes é irmã do Sr. Paulo Guedes, e foi eleita presidente da ANUP em maio de 2019, ou seja, posteriormente à posse de seu irmão como ministro da Economia do Brasil. 
- As IES com fins lucrativos são possuídas e operadas por empresas. Tal como acontece com outras empresas, eles são em última instância responsáveis perante a lei pelo retorno aos acionistas. A investigação descobriu que as faculdades com fins lucrativos geridas por investidores têm como meta principal fazer rápido retorno do seu investimento;

- Essas IES utilizam, de maneira geral, um recrutamento de alunos agressivo e enganoso. A obrigação de satisfazer os acionistas significa que muitas faculdades com fins lucrativos estabelecem como meta um aumento na taxa de matrícula com base nas projeções financeiras internas da empresa, em vez da missão de educar os alunos;

- Essas IES tiveram taxa de abandono excessiva, quando comparada com as demais instituições de ensino superior: foram 596.556 estudantes que se inscreveram em 2008-9 e não retornaram no ano seguinte, ou seja, 54\% dos estudantes ingressantes. A grande maioria dos estudantes deixou o ensino superior com uma dívida de empréstimo que irá segui-los ao longo de suas vidas e pode criar um encargo financeiro que é extremamente difícil, e às vezes impossível, de quitar.

No Brasil, estamos diante de uma situação gravíssima, em que é muito maior o percentual de alunos que provavelmente estão sendo submetidos a questões parecidas. Em particular, aparentemente, alguns grandes grupos empresariais estão conquistando um público de baixa renda muito vulnerável ao sonho do diploma de ensino superior, porém com pequena capacidade de questionar a qualidade do ensino que é ofertado e sem a necessária proteção do Estado brasileiro na tarefa, diferentemente do que acontece em áreas como a de medicamentos, via Anvisa e Ministério da Saúde, por exemplo. Isso impacta todo o conjunto das IES privadas que, de maneira geral, tende a se sentir impelido a competir com as mesmas armas, comprimindo custos e baixando a qualidade da diplomação.

Chama a atenção que os dois grupos privados com maior número de alunos matriculados, Kroton e Unip, que tinham em 2018 cerca de 15\% de todos os alunos do ensino superior do país e $21,7 \%$ dos alunos das IES privadas, apresentem resultados tão preocupantes: cerca de 50\% de seus alunos evadem nos dois primeiros anos do curso e, para os sobreviventes, cerca de $50 \%$ estão em cursos com nota no Enade 1 ou 2, em franco desacordo com a média do desempenho dos demais alunos das IES particulares e públicas do país.

Apesar de não ser uma tendência internacional, a autorregulação é defendida com base no "sucesso autoproclamado" pelos grandes grupos privados, como mostra a fala da presidente da Anup, associação que representa 
os grandes grupos privados (CNE, 2020): "Na verdade, poucos países do mundo têm uma educação superior tão pujante e um setor de educação superior tão bem estruturado como nós".

O presente trabalho não encontra evidências de que estamos em uma boa trajetória no ensino superior privado no atual momento; ao contrário, os resultados aqui apresentados indicam um futuro preocupante para o ensino superior, sem uma contrapartida clara para os interesses da população e do país que justifique essa reorganização da oferta do setor privado.

\section{REFERÊNCIAS}

AMARAL, N.; BIELSCHOWSKY, C. (2020). Custo aluno/ano das IES do Brasil. Trabalho com resultados já calculados e analisados, em fase de elaboração do texto.

BIELSCHOWSKY, C. (2017). Consórcio Cederj: A História da Construção do Projeto. EaD em Foco, v. 7(2). doi: https://doi.org/10.18264/eadf.v7i2.652.

BIELSCHOWSKY, C. E.; MASUDA, M. (2017). Diplomação na Educação Superior a Distância. EmRede, Revista da Educação a Distância, v. 5, no 1.

BIELSCHOWSKY, C. (2018). Qualidade na educação superior a distância no Brasil: onde estamos, para onde vamos? EaD em Foco, v. 8(1). doi: https://doi. org/10.18264/EaDf.v8i1.709

BIELSCHOWSKY, C. (2018). Análise dos resultados do Exame Nacional de Desempenho de Estudantes (Enade) para Educação a Distância do ciclo 2015 a 2017. EaD em Foco, v. 8(1). doi: https://doi.org/10.18264/eadf.v8i1.758.

CONSELHO ADMINISTRATIVO DE DEFESA ECONÔMICA - CADE (2016). Atos de Concentração no Mercado de Prestação de Serviços de Ensino Superior. Disponível em: http://www.cade.gov.br/acesso-ainformacao/publicacoes-institucionais/dee-publicacoes-anexos/caderno-deeducacao-20-05-2016.pdf

CONSELHO NACIONAL DE EDUCAÇÃO (2019). Os riscos e as oportunidades da autorregulação da educação superior brasileira. Palestra proferida no dia 4 de dezembro pela Sra. Elizabeth Guedes. Disponível em: https: / / www.youtube.com/watch?v=7YuHrPIcnoE\&feature=youtu.be 
$\operatorname{INEP}$ (s/d). Microdados do Censo da Educação Superior e do Enade. Disponível em: http://portal.inep.gov.br/web/guest/microdados

INEP (2018). Nota Técnica no 37/2019/CGCQES/DAES. Disponível em: http://download.inep.gov.br/educacao_superior/enade/notas_tecnicas/2018/ nt_37-2019_IGC-2018.pdf

KNOBEL, M.; VERHINE, R. (2017). Brazil's For-Profit Higher Education Dilemma. International Higher Education, v. 23. doi: http://dx.doi/ org/10.6017/ihe.2017.89.9769

KWIEK. M. (2018). Private Higher Education in Developed Countries. Encyclopedia of International Higher Education Systems and Institutions. TEIXEIRA, P.; SHIN, J. C. (Eds.). New York: Springer, p. 1-9.

LEVY, D. C. (2018). Global private higher education: an empirical profile of its size and geographical shape. High Educ., v. 76, p. 701. doi: https://doi. org/10.1007/s10734-018-0233-6

MARQUES, W. (2013). Expansão e oligopolização da educação superior no Brasil. Avaliação, Campinas, v. 18, nº 1. doi: http://dx.doi.org/10.1590/S141440772013000100005

MEC (2003; 2007). Referenciais de Qualidade para EaD. Disponíveis em: http:/ / portal.mec.gov.br/par/193-secretarias-112877938/seed-educacao-adistancia-96734370/12777-referenciais-de-qualidade-para-ead

MEC (2019). Ministro defende autorregulação para instituições privadas de ensino superior. Disponível em: http:/ / portal.mec.gov.br/component/content/ article/212-noticias/educacao-superior-1690610854/80691-ministro-defendeautorregulacao-para-instituicoes-privadas-de-ensino-superior?Itemid=164

NEDER, M. L. C. (2004). A educação a distância no contexto das políticas da UFMT. Universidade e Democracia. Cuiabá: Editora da UFMG, p. 79-86.

PROPHE (2018). The program for research on private higher education. Dados compilados para 131 países do mundo referentes à oferta em 2010, organizados a partir da sistematização de diferentes fontes. Disponível em: http://prophe.org/. Último acesso em: 11 jan. 2018. 
SOUZA, J. A.; MENDONÇA, D. J.; SILVA, B. C.; BENDICTO, G. C. de (2017). Desempenho econômico da maior empresa de serviços educacionais do mundo: um estudo da Kroton Educacional com base em seus segmentos operacionais. Cuad. Contab., Bogotá, v. 18, no 46, july/dec. 2017. doi: http:// dx.doi.org/10.11144/javeriana.cc18-46.deme

VERHINE, R.; LYS, V. D. (2017). Educação superior com fins lucrativos e responsabilidade social. Artigo publicado na Associação Brasileira de Ensino Superior (ABMES), dezembro de 2017. Disponível em: https://www. responsabilidadesocial.abmes.org.br/noticias/artigos/254-educacao-superiorcom-fins-lucrativos-e-responsabilidade-social

UNESCO (2019). Unesco Institute for Statistics database. Disponível em: http://tcg.uis.unesco.org/4-3-2-gross-enrolment-ratio-for-tertiary-education/ e em: http://data.uis.unesco.org/index.aspx?queryid $=3442$

UNITED STATES DEPARTMENT OF EDUCATION (2018). The Condition of Education 2016. Washington: National Center for Education Statistics. Disponível em: https://nces.ed.gov/pubs2018/2018144.pdf

UNITED STATES SENATE (2012). For profit higher education. Report of the Health, Education, Labor and Pensions Committee. Washington: U. S. Senate. Disponível em https://www.help.senate.gov/imo/media/for_profit_report/ PartI-PartIII-SelectedAppendixes.pdf

\section{AGRADECIMENTOS}

O autor agradece aos Drs. Esteban Moreno (CECIERJ), Ricardo Bielschowsky (UFRJ) e Roberto Bielschowsky (UFRJ) por suas importantes contribuições. 


\section{Carlos Eduardo Bielschowsky}

Doutor em Física pelo Centro Brasileiro de Pesquisas Físicas. Professor Associado do Instituito de Química da UFRJ. Presidente da Câmara de Educação Básica do Conselho Estadual de Educação do Rio de Janeiro. Presidiu por 18 anos a Fundação Cecierj, tendo planejado e implementado o consórcio Cederj e foi Secretário de Educação a Distância do MEC entre 2007 e 2010, tendo participado da criação da Universidade Aberta do Brasil, do e-tec Brasil, do Proinfo integrado e do Plano Nacional de Formação de Professores, além da atuação na regulação e supervisão da Ead do país. E-mail: carledubiel@gmail. com

Recebido em 28 de janeiro de 2020. Aprovado em 04 de março de 2020. 